\title{
HUBUNGAN KEGEMARAN MEMBACA SURAT KABAR DENGAN KEMAMPUAN MENEMUKAN KATA SERAPAN DALAM SURAT KABAR PADA SISWA KELAS XI SMA SWATA TUNAS PELITA BINJAI
}

\author{
Jepri Arizal \\ STKIP Budidaya Binjai
}

\begin{abstract}
Abstrak
Penelitian ini bertujuan mengetahui Hubungan Kegemaran Membaca Surat Kabar dengan Kemampuan Menemukan Kata Serapan dalam Surat Kabar Oleh Siswa Kelas XI SMA Swasta Tunas Pelita Binjai. Metode penelitian yang digunakan adalah metode deskriptif. Dalam pengolahan dan analisis data dilakukan melalui teknik analisis korelasi product moment. Populasi penelitian ini adalah siswa kelas XI SMA Swasta Tunas Pelita Binjai yang berjumlah 34 Siswa. Sampel yang diambil seluruh siswa kelas XI yaitu 34 siswa. Data yang penulis kumpulkan melalui pengisian angket mengenai kegemaran membaca surat kabar dan tes untuk mengukur kemampuan siswa dalam menemukan kata serapan. Setelah dianalisis, diketahui bahwa dari pengisian angket dan tes menemukan kata serapan berada dalam tingkatan baik. Dalam menemukan kata serapan rata-rata siswa mendapatkan nilai 8. Sedangkan hubungan $\left(r_{x y}\right)$ diperoleh sebesar 0,98. Setelah dikonsultasikan dengan r. tabel pada db 41 dan tingkat kepercayaan 95\% diketahui r. hitung ( 0,98 $)>$ r. tabel ( 0,279). Berdasarkan perbandingan yang diperoleh maka hipotesis yang berbunyi “ Ada hubungan kegemaran membaca surat kabar dengan kemampuan menemukan kata serapan dalam surat kabar oleh siswa kelas XI SMA Swata Tunas Pelita Binjai “ diterima.
\end{abstract}

Kata Kunci : Membaca, Surat kabar

\section{PENDAHULUAN}

Keterampilan berbahasa dalam kurikulum di sekolah biasanya mencakup empat segi yaitu : keterampilan menyimak, keterampilan berbicara, keterampilan membaca dan keterampilan menulis. Salah satu aspek dari empat dalam keterampilan berbahasa tersebut ialah membaca. Henry Guntur Tarigan (2005:7) Membaca adalah suatu proses yang dilakukan serta dipergunakan oleh pembaca untuk memperoleh pesan, yang hendak disampaikan oleh penulis melalui media kata-kata/bahasa tulis. Kegiatan membaca telah dimulai sejak siswa memasuki pendidikan di Sekolah Dasar. Rendahnya kualitas membaca siswa akhir-akhir ini, mulai dari lulusan SD hingga perguruan tinggi dan relativ minimnya penulis-penulis muda yang berkarya,agaknya telah menjadi bukti gagal mencapai tujuan yang telah ditargetkan yang dengan sendirinya kegagalan dalam menolong siswa dalam dua kepentingan tadi.

Seorang pelajar, berbahasa didahului menyimak/mendengarkan bahasa, lalu meniru atau mengucapkannya. Dengan kata lain berbicara. Setelah keterampilan berbicara dimiliki, seseorang mulai belajar membaca dan menulis. 
Donal E. Birds juga pernah mengadakan penelitian tentang aktivitas siswa disebuah sekolah dan hasilnya terbagi atas menyimak 42\%, berbicara $25 \%$, membaca $15 \%$ dan menulis $18 \%$. Menurut pendapat tersebut kita ketahui kegiatan membaca lebih kecil dari kegiatan yang lain. Namun kita sadari bahwa membaca mempunyai peranan yang penting dalam kehidupan sehari-hari. Terlebih-lebih di zaman globalisasi pada saat sekarang. Informasi datang begitu cepat, datang silih berganti. Apabila kita tidak menguasai informasi, maka kesempatan untuk menggenggam dunia hilang. Salah satunya adalah dengan membaca.

Menurut Henry Guntur Tarigan Membaca adalah suatu proses yang dilakukan oleh pembaca untuk memperoleh pesan yang hendak disampaikan oleh penulis melalui media kata-kata atau bahasa tulis. Suatu proses yang menuntut agar kelompok kata yang merupakan suatu kesatuan akan terlihat dalam suatu pandangan sekilas, dan agar makna kata-kata secara individual akan dapat diketahui. Kalau hal ini tidak

terpenuhi, maka pesan yang tersurat dan yang tersirat tidak akan tertangkap atau dipahami, dan proses membaca itu tidak terlaksana dengan baik ( Hudgson 1960 : 43 $44)$.

Sedangkan menurut Tampubolon (1987:5) membaca adalah satu dari empat kemampuan bahasa pokok, dan merupakan satu bagian atau komponen dari komunikasi tulisan. Dalam komunikasi tulisan, sebagaimana telah dikatakan, lambang-lambang bunyi bahasa diubah menjadi lambang-lambang tulisan atau huruf-huruf, dalam hal ini hurufhuruf alfabet latin.

Dari kedua pendapat di atas, dapat kita tarik kesimpulan bahwa membaca merupakan proses untuk memperoleh pesan atau informasi melalui bahasa tulis dalam bentuk alfabet. Ada saatnya pada tahap membaca tertentu, kemampuan intelektual dibutuhkan, dan pada saat yang lain dibutuhkan faktor pengetahuan, pengalaman dan persepsi untuk menelaah, menilai atau membuat imajinasi. Terlebih ketika membaca surat kabar dibutuhkan waktu dan kemampuan untuk menelaah isi yang terdapat dalam surat kabar tersebut. Pada taraf penerimaan lambang-lambang tulisan diperlukan kemampuankemampuan motoris berupa gerakan-gerakan mata, kebanyakan dari kegiatan-kegiatan dalam membaca pada tingkatan ini adalah kegiatan-kegiatan pikiran atau penalaran termasuk ingatan.

Dewasa ini surat kabar sudah semakin menjamur di pasaran. Sudah semakin mudah kita mendapatkan informasi melalui media surat kabar. Harga yang relatif terjangkau untuk bisa membeli surat kabar tersebut. Terlebih bagi siswa - siswi Sekolah Menengah Atas ( SMA ), mereka bisa lebih mudah memperoleh informasi melalui surat kabar dengan harga yang relatif murah.

\section{METODE PENELITIAN}

Penelitian ini dilaksanakan di SMA Swasta Tunas Pelita Binjai yang berlokasi di Jl. Perintis Kemedekaan, Kelurahan Kebun Lada, Kecamatan Binjai Utara.

Dari peninjauan yang dilakukan, diperoleh data seluruh siswa kelas XI SMA Tunas Pelita Binjai berjumlah 34 yang tersebar dalam 1 kelas.

\section{Instrumen Penelitian}

Untuk memperoleh data yang dipergunakan dalam penelitian ini, penulis menggunakan alat pengumpulan data yang disebut instrumen. Instrumen penelitian yang penulis gunakan dalam pengumpulan data ini adalah angket dan tes, yaitu : 
1. Pengisian angket kegemaran membaca surat kabar

Pengisian angket ini dengan mengajukan pertanyaan-pertanyaan secara tertulis kepada responden yaitu kepada 34 orang siswa yang telah terpilih sebagai sampel dalam penelitian ini.

2. Tes kemampuan menemukan kata serapan dalam surat kabar

Dalam tes ini siswa disuruh mencari kata serapan yang terdapat pada surat kabar yang telah disiapkan. Banyak kata yang harus dicari sebanyak 20 kata serapan.

\section{Teknik Analisis Data}

Teknik analisis data adalah suatu kegiatan dalam mengklasifikasikan data serta memaknai data yang telah diperoleh. Untuk menganalisis data penelitian digunakan langkah-langkah sebagai berikut :

1. Menghitung skor tes kemampuan menemukan kata serapan yang terdapat dalam surat kabar, kemudian mengubah skor menjadi nilai akhir dengan cara

Jumlah skor yang benar $\times 10$

Jumlah soal

Selanjutnya mencari nilai rata-rata kemampuan menemukan kata serapan yang terdapat dalam surat kabar, dengan cara membagi jumlah keseluruhan nilai dengan jumlah sampel.

Kemudian pengolahan tes di atas, diklasifikasikan dengan skala nominal yang dinyatakan sesuai dengan pendapat Arikunto :

- Kemampuan sangat baik bila nilai 9-10

- Kemampuan baik bila nilai 7-8

- Kemampuan sedang bila nilai 6

- Kemampuan kurang bila nilai 5

- Kemampuan sangat kurang bila nilai 4 atau lebih kecil.

2. Menggunakan hubungan kegemaran membaca surat kabar dengan kemampuan menemukan kata serapan dalam surat kabar dengan menggunakan rumus Product Moment :

$$
\mathrm{r}_{\mathrm{xy}}=\quad \frac{\sum \mathrm{xy}}{\sqrt{\left(\sum x^{2}\right)\left(\sum y^{2}\right)}}
$$

Keterangan :

$\mathrm{r}_{\mathrm{xy}} \quad=$ Koefisien korelasi antara variabel $\mathrm{X}$ dengan variabel $\mathrm{Y}$

$\Sigma X Y=$ Jumlah hasil perkalian antara variabel $\mathrm{X}$ dan $\mathrm{Y}$

$\sum X^{2} \quad=$ Jumlah kuadrat skor variabel $X$

$\sum Y^{2} \quad=$ Jumlah kuadrat skor variabel $Y$

\section{Pengujian Hipotesis}

Untuk menguji hipotesis penelitian ini dilakukan dengan cara mengkonfirmasikan besarnya $r$ hitung dengan $r$ tabel pada tingkat kepercayaan

$95 \%$ dari derajat kebebasan sesuai sampel. Apabila $r$ hitung $>r$ tabel, maka hipotesis diterima.

\section{HASIL DAN PEMBAHASAN}


Untuk mendapatkan data dalam penelitian ini saya sebagai peneliti menggunakan angket untuk mengetahui kegemaran membaca surat kabar dan menggunakan tes mencari kata serapan dalam surat kabar.

Setelah dilakukan penelitian terhadap siswa kelas XI SMA Swasta

Tunas Pelita Binjai tentang Hubungan Kegemaran Membaca Surat Kabar dengan Kemampuan Menemukan Kata Serapan dalam Surat Kabar, maka diperoleh data sebagai berikut

1. Data hasil angket tentang kegemaran siswa dalam membaca surat kabar.

2. Menghitung skor kemampuan

3. menemukan kata serapan dalam surat kabar kemudian mengubah skor menjadi nilai akhir. 
4. Mencari nilai rata-rata siswa dalam menemukan kata serapan

Dari tabel 4.3 di atas diperoileh nilai rata-rata menemukan kata serapan dalam surat kabar dengan cara : $\mathrm{M}=$ Jumlah Nilai akhir

$$
M=\frac{261}{34}=7,67
$$

Dan dibulatkan menjadi 8

5. Kemudian dari pengolahan tes di atas, dapat diklasifikaikan dengan skala nominal yang dinyatakan sesuai dengan pendapat Arikunto :

Kemampuan sangat baik bila nilai 9-10

Kemampuan baik bila nilai 7-8

Kemampuan sedang bila nilai 6

Kemampuan kurang bila nilai 5

Kemampuan sangat kurang nilai 4 atu lebih keil

Dengan demikian hasil penelitian ini menyatakan hubungan kegemaran membaca surat kabar dengan kemampuan menemukan kata serapan dalam surat kabar oleh siswa kelas XI SMA Swasta Tunas Pelita Binjai pada tingkat kemampuan baik.

6. Mencari hubungan antara kegemaran membaca Surat kabar dengan kemampuan menemukan kata serapan dalam surat kabar.

Untuk mengetahui korelasi antara Kegemaran membaca surat kabar dengan kemapuan menemukan kata serapan dalam surat kabar maka dapat di pakai rumus korelasi product moment

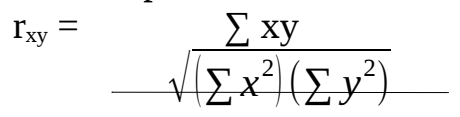

Berdasarkan tabel di atas dapat dicari korelasi kegemaran membaca surat kabar dengan kemampuan menemukan kata serapan dalam surat kabar oleh siswa kelas XI SMA Swasta Tunas Pelita Binjai sebagai berikut

$$
\begin{aligned}
\mathrm{r}_{\mathrm{xy}}= & \frac{\sum \mathrm{xy}}{\sqrt{\left(\sum x^{2}\right)\left(\sum y^{2}\right)}} \\
= & \frac{1912,28}{\sqrt{(1838,98)(2070)}} \\
= & \frac{1912,28}{\sqrt{3806688,6}} \\
= & 1912,28 \\
= & \frac{1951,07}{0,98}
\end{aligned}
$$

\section{Pengujian Hipotesis}


Berdasarkan hasil perhitungan di atas diketahui indeks korelasi $\left(\mathrm{r}_{\mathrm{xy}}\right)$ sebesar 0,98. Untuk menafsirkan besarnya korelasi ini peneliti berpatokan pada pendapat Surachmad yang menyatakan :

$0,00-0,20$ korelasi yang rendah sekali

0,20 - 0,40 korelasi yang rendah tetapi ada

$0,40-0,90$ korelasi yang tinggi

$0,90-1,00$ korelasi yang tinggi sekali.

Bersasarkan patokan/ kriteria di atas maka dapat dikatakan bahwa hubungan kegemaran membaca surat kabar dengan kemampuan menemukan kata serapan dalam surat oleh siswa kelas XI SMA Swasta Tunas Pelita Binjai berada pada tingkat yang tinggi sekali. Selanjutnya $\mathrm{r}_{\mathrm{xy}}$ hasil perhitungan ini dikonfirmasikan dengan $\mathrm{F}$ tabel pada $\mathrm{db} 43-2$ ( 41) dengan taraf signifikan 95\% = 0,279. Karena $r$ hitung $(0,98)>r$ tabel $(0,279)$ sesuai dengan ketentuan pengujian hipotesis, maka hipotesis penelitian yang berbunyi " ada hubungan kegemaran membaca surat kabar dengan kemampuan menemukan kata serapan dalam surat kabar oleh siswa kelas XI SMA Swasta Tunas Pelita Binjai ” dapat diterima.

\section{KESIMPULAN}

Berdasarkan dari pengolahan data yang telah saya selesaikan pada skripsi ini, maka saya sebagai peneliti dapat menyimpulkan bahwa hubungan kegemaran membaca surat kabar dengan kemapuan menemukan kata serapan dalam surat kabar oleh siswa kelas XI SMA Swasta Tunas Pelita Binjai adalah sebagai berikut :

1. Kegemaran siswa dalam membaca surat kabar sudah cukup baik.

2. Kemampuan siswa dalam menemukan kata serapan berada pada tingkat baik dengan nilai 8.

3. Hubungan kegemaran membaca surat kabar dengan kemampuan menemukan kata serapan dalam surat kabar oleh siswa kelas XI SMA Swasta Tunas Pelita Binjai Tahun Pelajaran 2013/2014 berada pada rentangan yang tinggi sekali yaitu sebesar 0,98 .

\section{DAFTAR PUSTAKA}

Ali, Muhammad, 1986, Penelitian Kependidikan Prosedur dan Strategi, Bandung : Angkasa.

\section{Angkasa.}

1987, Penelitian Kependidikan Prosedur dan Strategi, Bandung :

Arikunto, Suharsimi, 2001, Manajemen Penelitian, Jakarta : Bumi Aksara. 2006, Prosedur Penelitian Suatu Pendekatan Praktik, Jakarta : PT

Rhineka Cipta.

Departemen Pendidikan dan Kebudayaan,2008, Kamus Besar Bahasa Indonesia, Jakarta : PT. Grramedia Pustaka Utama.

Faisal, Sanafiah dan G.W, Mulyadi, 1982, Metodologi Penelitian Pendidikan dan 
Strategi, Surabaya.

Tarigan, Henry Guntur, 2005, Membaca Sebagai Suatu Keterampilan Berbahasa, Bandung : Angkasa.

Soedarso , 1991, Sistem Membaca Cepat dan Efektif, Jakarta : PT Gramedia Pustaka Utama.

Sugiono, 2009, Metode Penelitian Pendidikan, Bandung : CV. Alfabeta.

Surakhmad, Winarno.2000. Pengantar Ilmiah Dasar Metod dan Teknik. Banndung : Tarsito.

Surya Brata, Sumahadi, 1983, Metodologi Penelitian, Jakarta : Rajawali.

Tampubolon, 1987,Kemampuan Membaca dan Teknik Membaca Efektif dan Efisien, Bandung : Angkasa.

Winarno, Surachmad, 2001, Penelitian Kependidikan Ilmiah Dasar Metode Teknik, Bandung : Tarsito. 